\title{
8. Drawing lines in US monetary and fiscal history
}

\section{Thomas J. Sargent ${ }^{1}$}

Economists now widely use the powerful notion of 'equilibrium'. It is different from the notion that physicists use. It does not mean a system at rest, where there is no propensity to change. It is a description of a system that consists of many people with their own motives, interests, incentives, information, opportunities and constraints. The notion of equilibrium is that things have settled down to a situation where at that particular point in time no one has incentive to deviate, given what everybody else is doing. The system has come to rest in that sense. Technically, that is the notion behind competitive equilibrium or Nash equilibrium, which pervades economics.

That sets the stage for the following meaningful anecdote. I went to a dinner at the Hoover Institution with a small group of friends in the 1980s. Milton Friedman and George Stigler were there. They were very good friends and leaders in creating the Chicago School of Economics in the 1950s and 1960s, but they often had very different views of things. Stigler viewed his job as interpretive, to understand the world as it was. You 
would ask him, 'Do you want to improve things?' 'No,' he would say, 'my job is to explain them as equilibrium outcomes.' So he did not give advice. But, Milton Friedman spent part of his career as a public intellectual giving advice to the government. After a few drinks, Stigler asked Friedman, 'So, Milton, do you ever work as a consultant for businesses?' - knowing that he never did. Milton Friedman said, 'No, I wouldn't consult business. You know, they're optimizing; and they know what they're doing much better than I could tell them to do.' Then Stigler paused for a minute and he said, 'Well, why in the hell are you always trying to tell the government what to do?' It is the only time I ever saw Milton Friedman speechless.

There is a message in this anecdote. Those two poles of opinion are about whether one could have much to say about monetary policy or whether the Federal Reserve itself was a bad idea. I will come back to that, but my principal theme is about where to draw lines between the markets for money and credit; and between monetary and fiscal policies.

These lines are drawn by the government or the collective. US history is full of a long struggle about exactly where to draw these lines. The struggle continues to this day. One example: should Congress be prevented from issuing a paper money? The people at the Constitutional Convention thought they had prohibited this. If Congress did issue a paper money should there be a legal tender? At the Constitution Convention 
everyone presumed there should never be a legal tender. Read the debate on August 16, 1787, in Madison's notes. Should there be federal bailouts of state governments? Our Republic was born with a massive bailout of state governments.

Finally, should there be a central bank and, if so, what should a central bank do? It has been difficult for our country to make up its mind about a central bank. I will take Richard Sylla's line - in 1791 our country said yes. In 1811 it said no. In 1816 it said yes. In 1832 it said no. And in 1913 it said yes. But then it said, what, do you mean by ' $a$ ' central bank? We will have 12 or 13, in honor of Andrew Jackson's memory, who said we should have none. This was echoed in the opinions and the decisions of individual people. James Madison, the original author of the 'no' position in 1791 said yes after the British burned his house - the White House. And in 1832 he said yes again. He voted against Andrew Jackson during that campaign. Henry Clay, Abraham Lincoln's hero - one of mine, too - said no in 1811 and yes in 1832. And Andrew Jackson had some fun with that. He quoted Henry Clay's 1811 speech in his message vetoing the rechartering of the Bank of the United States.

So what should a central bank do, now that we have one? It was born with the advice that it should purchase real bills; in 1913 that was written into the Federal Reserve Act. In 1935 the law was revised to say, do not touch the stuff. That held until 2008. Now are we holding real bills again - and what is a 'real bill' anyway? 
In this talk, I am going to try to understand why politicians - and I think politicians just do what voters want most of the time - have such a tough time making up their minds about these things. I will advance the hypothesis that maybe what underlies these historical difficulties and instabilities are uncertainties and close calls coming from the theories that inform monetary and fiscal policies. My main text is going to be the quantity theory of money versus the real bills doctrine, or regulation versus free banking, or price level stability versus efficiency. Those are all versions of the same thing. And related by a little more of a stretch is lender of last resort and deposit insurance; is it good or bad? I am going to talk mostly about central banks and banking. The theme is as old as the hills: What kind of assets should financial intermediaries be permitted to hold? What kind of liabilities should they issue? And who is going to decide that? The names of the liabilities and the names of the assets have changed, but the underlying theoretical issues endure.

George Stigler once said: '[a] war can ravage half a continent and raise no new issues in economic theory'. People often ask economists: what did you learn new from this financial crisis? What new did you learn that you did not previously know after you read the papers about the crises of 1893 and 1907 and 1933? I prefer not to answer that question.

In A Program for Monetary Stability, Milton Friedman (1960, p.8) wrote: 
The appropriateness of government responsibility for the monetary system has, of course, been long and widely recognized. This habitual and by now almost unthinking acceptance of government responsibility makes thorough understanding of the grounds for such responsibility all the more necessary, since that acceptance enhances the danger that the scope of government intervention will spread from activities that are to those that are not appropriate in a free society, from providing a monetary framework to determine the allocation of resources among individuals.

It is Adam Smith and the real bills doctrine, also known as free banking, in one corner, versus narrow banking and 100 percent reserves in the other corner. And they are diametrically opposed. Or are they? The real bills doctrine was written into the Federal Reserve Act, the original one. But it came to be known at the University of Chicago as the real bills fallacy. Smith argued fair and square. He did not conjure up straw men and then beat them up. He was seeking to dismantle a system of economic policy known as mercantilism, which he interpreted as a set of restrictions designed to protect the domestic monetary system from disturbances that came from the trade balance. When you are on an international gold standard, trade imbalances cause inflows and outflows of gold, which are threatening. Smith interprets mercantilism as a set of measures designed to stabilize the domestic monetary system and isolate it from those disturbances. In modern language, Smith criticizes mercantilism as inefficient. The Wealth of Nations (Smith, 1776) is about capitalism, free 
competition, free markets, and free trade. But Smith spends about a quarter to a third of the book talking about money, because he wants to propose an alternative monetary system that will disarm this defense of mercantilism.

Smith says, suppose you are on the commodity money standard where only coins are circulating. You are a small country. He has England in mind. Initially banks are prohibited from issuing circulating bank notes. Suppose, however, that banks can issue bank notes that say, 'I owe you this much gold.' On the liability side of the bank balance sheet it says 'bank notes'. On the asset side of the balance sheet is not 'gold' but what Adam Smith called 'real bills'. Those are shortterm safe evidences of private indebtedness. So, the bank issues bank notes backed not by gold, but by things that are going to be convertible into gold soon. If you allow this, Smith predicts - it is nice general equilibrium reasoning - these self-liquidating private loans will be as good as gold. The new system will result in a one-time exportation of monetary gold. There will be no rise in the domestic price level. Goods used for consumption will flow into the country; there will be a consumption boom.

On this basis he recommends free banking and disarms the mercantilists' defense of their restrictions. It is brilliant economic analysis and is the birth of the real bills doctrine. What is a real bill? Smith defines a 'real bill' this way in The Wealth of Nations: 'A bank discounts to a merchant a real 
bill of exchange drawn by a real creditor upon a real debtor, and which as soon as it becomes due is really paid by that debtor.' That is what he means by the real bills doctrine. He is struggling with his wording because he does not know what a random variable is. He is trying to say that it is 'riskless'. Competition is going to force the banks to issue these notes backed by very good quality loans.

There are two ways to implement the real bills doctrine: either by free banking or, if you do not have free banking and you are stuck with a central bank, there is a way to get the central bank - basically through the back door - to implement the real bills doctrine. This was what was written into the Federal Reserve Act. It is to freely discount banks' holding of safe private securities at an interest rate set (as stated in the Federal Reserve Act) 'with the view of accommodating commerce and business'. It can be shown, using a little economic theory, that those two things are equivalent.

The real bills doctrine came to be regarded as promising that the money supply would regulate itself. It won the day in some places, but did not in other places. The whole grounds for it are economic efficiency. You will notice if you follow debates at the International Monetary Fund now, there are lots of countries that are attempting - people call it neo-mercantilism - to reimpose mercantilist measures, precisely to protect the domestic monetary arrangements. That is what is going on in, for example, Brazil. 
But one place that the real bills doctrine came to be disputed was a place that held The Wealth of Nations in the greatest esteem; the University of Chicago. The real bills doctrine came in for widespread criticism, especially after the gold standard price level anchor that Smith had assumed had disappeared when we went to a fiat money standard. They argued that the real bills doctrine or free banking under a fiat money standard would not stabilize the price level, it would unhinge the price level; there would be no nominal anchor once gold was gone, and you would get a great deal of price level instability. It is at this point, in the hands of Irving Fisher and his followers, the quantity theory started to become popular.

When I say the 'real bills doctrine', I do not drench the words with contempt. Many people do. Liaquat Ahamed's Lords of Finance (2009) - a wonderful book - mentions the real bills doctrine many times. But every time it does, Ahamed says that the person who believed it or asserted it was stupid. He does not mention that Adam Smith was the doctrine's author.

So which was right, the real bills doctrine or the quantity theory of money? The quantity theory of money is based on an empirical relationship between the quantity of money and prices, where the quantity of money is somehow defined as some notes, perhaps issued by the government, perhaps issued by the private sector, and there is a demand function for money.

If you want to stabilize the price level, you have 
to stabilize the money supply. The assertion is that the real bills doctrine would not do it; it left the money supply uncontrolled.

The Chicago Plan for Banking Reform (developed in the 1930s, following the banking failures of the Great Depression) required 100 percent reserves. You could think of it as killing banks. If you issue any liability, like a bank note or a deposit that claims to be a perfectly safe claim on currency, you have to hold the currency in a warehouse. In effect, government is given a monopoly on the right to issue currency. The monopoly is enforced by 100 percent reserves. It is the opposite of free banking and the real bills doctrine.

In his Program for Monetary Stability, Milton Friedman advocated a revised version of narrow banking. Think of what Adam Smith was trying to do. He was trying to integrate markets for money and credit. He was letting people intermediate credit and issue notes that were just evidences of intermediated IOUs from the private sector. He was putting the markets together. The 100 percent reserves requirement, on the other hand, totally separates them. The market for credit is one thing. And the market for IOUs is another thing. That was Friedman's device for isolating fluctuations and demand for credit from doing anything to the price level. He was willing to pay a big price for that, or at least he seemed to be at the beginning.

Lloyd Mints and others at the University of Chicago in the 1930s were willing to pay a big price for stability; the big price was economic 
inefficiency. Under this set-up, there are private IOUs that are perfectly safe that bear a higher rate than the money, creating an arbitrage opportunity. There is a rate of return discrepancy the same liabilities are bearing different rates of return, different prices. But Friedman hated inefficiencies, so in A Program for Monetary Stability, he amended the original Chicago proposal. He proposed that the Federal Reserve or the central bank pay interest on reserves at the market rate of interest. Why? Because he wanted to prevent the rate of return discrepancies. First, the discrepancy is an indication of inefficiency. Second, it is an indication that there is an incentive for avoidance; and smart guys are going to figure out how to avoid it. There is a hole in the system. Friedman is trying to repair it by having the central bank pay interest on reserves at the market rate.

But this causes a couple of problems. First, how is the central bank going to raise the revenues to pay interest on reserves? This is an issue right now that has been swept under the rug because the central bank now has the authority to pay interest on reserves. How are you going to pay for it? Friedman tells you in a footnote that there are two ways to pay for it. And it matters which you do. First, you can use tax revenues. So you are going to have to acquire fiscal authority to raise the revenues. Second you can cross your fingers and hope that you can finance it from the interest on the government portfolio - perhaps use your mortgage-backed securities. Third, which 
Friedman does not even mention, you can print money. Here is the problem. This proposal integrates markets by killing off this rate of return discrepancy, which was the inefficiency. It reintegrates markets for money and credit and reignites all the instabilities Friedman was concerned with in the first place.

Now, just to show how difficult this issue is, Madison changed his mind, but Salmon P. Chase, Lincoln's Secretary of Treasury, changed his mind even more dramatically. He was against legal tender to the death when he was a hardmoney Democrat. Then he imposed legal tender when he was Lincoln's Secretary of Treasury. And then when he was older and wiser as Chief Justice of the Supreme Court he declared unconstitutional his own acts as Secretary of Treasury. Friedman tells why he is also tempted to change his mind. He realizes both of these extreme positions - a government monopoly on money and free-banking - actually have much in common.

One thing I want to underline is that paying interest on reserves is political dynamite in terms of undermining the independence of the Fed. It is an act of fiscal policy. This is just one more illustration of how the sequence of government budget constraints and the fact that the central bank can earn seigniorage revenue means that the 'independence' of the Federal Reserve is a fiction. It is pure fiction. And everyone knows it. But perhaps it is a useful fiction. And that it may be a useful fiction comes from comparing what seemed to 
be diametrically opposing positions that Milton Friedman made for coordinating monetary and fiscal policy.

In 1949 Friedman proposed the debt and management policy in which the Federal Reserve purchases 100 percent of all government debt issued by the Treasury. It automatically finances 100 percent of all government deficits. Why on earth would Milton Friedman, an inflation hawk, propose that? It has got to be the following: Friedman said monetary inflation is everywhere a monetary phenomenon. Because of the budget constraints, that really means that inflation is everywhere a fiscal phenomenon. If you have a government that is running sustained deficits, and it refuses to depart from them, the only way to finance those is to inflate; to raise seigniorage revenues. In Friedman's view, the central bank tells the fiscal authority right up front, if you run up government debt we are going to monetize it all right away. If that brings up inflationary pressures, it is not our fault, it is yours. Get the deficit under control. That, I believe, is Friedman's logic.

In 1960 he proposed something that seemed diametrically opposed. He said the Fed should increase the monetary base at $\mathrm{K}$ percent a year, and $\mathrm{K}$ is practically zero - it is going to finance none of the deficit. The Federal Reserve would now be saying to the government, we are never going to monetize any government debt. If you want to sell it, then sell it on the market. Maybe you will find some domestic citizens, or even 
better some foreigners, who will buy it. The virtue of this policy is if the central bank can stick to it, they will force the government to balance the budget in the present value sense.

Just like the local school board, if it wants to issue a bond it is going to have to show to its creditors that it is going to raise the taxes to pay the interest on that bond. So in vacillating between such apparently opposite proposals, Friedman struggled to find a way for a responsible monetary authority to get the upper hand over the fiscal authorities in what can become a game of chicken presented by the unpleasant arithmetic of the government budget constraint. It is unpleasant, but it is true. I think it is fascinating to see unity in the apparent changes of the mind of Friedman. He was struggling with the underlying issues. Likewise, in the late 1970s and early 1980s conservatives in the United States advocated a federal balanced budget amendment and Milton Friedman was the head of a serious-minded committee to enact this proposal, which had a lot of support.

Remember that a real bill is 'safe evidence of an indebtedness'. Recent events raise the question: is it possible to create a safe evidence of private indebtedness from a bunch of assets that were originally unsafe, through the law of large numbers? Should banks and other intermediaries be allowed to improve efficiency by offering products that rely on statistical averaging and censoring to transform bundles of risky assets of various 
durations into much less risky assets, maybe even risk-free assets that can then back short-term riskfree deposits?

That question then raises issues about proper policies toward public lenders of last resort and suppliers of deposit insurance. I am going to argue that public lenders of last resort and public suppliers of deposit insurance are the same thing. When it comes to the issues of stability and efficiency, is deposit insurance good, or is deposit insurance bad; is lender of last resort activity good, or is lender of last resort activity bad? That is the question. My sense is that Ben Bernanke and many people at the Fed think that deposit insurance is good, and that it should be extended.

Let us consider two modern models of panic insurance. The Diamond-Dybvig (1983) model says deposit insurance is costless and very good, while the Kareken and Wallace (1978) model concludes that deposit insurance and a lender of last resort are unambiguously bad. Both models are internally consistent views of the world. They differ on critical assumptions. The tensions highlighted by these models really take you to the core of contemporary issues. Given current policy in the US and the rest of the world, you will hope and pray that the Diamond-Dybvig deposit insurance model is correct, because otherwise we are in for it.

The Diamond-Dybvig model describes a welfare-improving role for maturity-transforming insurance-supplying institutions. Maturity trans- 
forming means they issue short-term deposits and they hold on the asset side longer-term stuff. If the longer-term stuff is held long enough it is relatively risk free. The problem is if you liquidate it early you are going to take a haircut. If you can just get people to stick with the program, everything will work out. An institution that can supply this intermediating welfare-improving wealth insurance activity is a bank or a system of banks. The problem - which advocates of deposit insurance see all over the place - is multiple equilibria. Everything works out well if I leave my deposit in and only go get money when I really need it. And the same with you. If so, statistical averaging works out. The right fraction take out early, the right fraction take out late, investments do not get prematurely liquidated, everything proceeds in an orderly way, and it is welfare improving. That is one equilibrium. But, what if I am a depositor who does not really want my money now and I see that you are going to remove your deposits from the bank. I start scratching my head and think, 'Does he really need the money now? Maybe he is not actually going to the bank.' Meanwhile, he sees me looking like I might go to the bank. We all go to the bank. Why? Because it is first come, first served. If I get there first I get my money. Otherwise, I get much less. A bank run ensues and when there is a run, the bank has to liquidate its assets, and we get a very inferior outcome. There is one good equilibrium and a zillion bad ones.

But, what if there is a simple cure? If there is a 
government agency that offers deposit insurance it will knock out all the equilibria except the good one and furthermore, it will stop the run, because you get your deposit even if you get to the bank late. Because there are no more runs, it costs the government not a dime. It is a multiple equilibrium killer that is costless to the government.

If you are a central banker or a treasury official in 2008, and you have got the Diamond-Dybvig model stamped in your brain, you see multiple equilibria everywhere. You start seeing runs on banks. No problem, there is deposit insurance. Then someone comes up to you and says, 'I got my Diamond-Dybvig model here, but what is a bank?' You say, 'A bank, easy, it says B-A-N-K on it, on the door.' But wait a minute, read the Diamond-Dybvig paper carefully. A bank is a maturity-transforming risk-sharing institution. It issues short, buys risky stuff long, and uses statistical averages. Then the central banker exclaims: 'Oh, my gosh, it is a money market mutual fund, it is an insurance company, it is any shadow bank.' The list goes on. And all of those things are vulnerable to runs. So now the central banker says: 'We don't have enough deposit insurance.' Now we have a justification for bailing out everything in sight. Anytime you see an incipient run your job is to knock it out by stepping in and offering a bailout. And by the way the model says this will not cost anything.

I had dinner with some friends who manage hedge funds. They said the big mistake of Bernanke 
was not to bail out absolutely everything. And I asked them, what would have happened if Bernanke had bailed out everything? They said, we would have had a mild recession like we had in 1991. These Diamond-Dybvig advocates are very influential and they believe their model.

But Diamond-Dybvig left one important thing out: moral hazard. We need to read Kareken and Wallace's 1978 paper. The Kareken-Wallace model does not have multiple equilibria and does not have runs, but it has got deposit insurance. For every risk there is a competitive market that allows you to insure it. If you want Greek government debt, you can take bets on whether or not that will survive. Kareken-Wallace shows that for a bank to offer safe deposits, it will have to hold a perfectly safe portfolio. Who will monitor this? The depositors. There is a bank out there offering you a very high interest rate, but it is holding dodgy stuff. You will go there if you are willing to take the risk. If you want to hold safe stuff you will go to a bank that is holding a safe portfolio; no government regulations needed.

Now add deposit insurance. (I am going to simplify this a bit.) Deposit insurance is supplied by the government and is free. A bank can now attract deposits no matter how risky it is. Because of the insurance, the depositors do not care. So now the monitoring incentives of the depositors have gone out the window. What is in the interest of the shareholders of the bank?

The bank should become as risky as possible, 
and as large as possible. And the bigger, the more that maximizes the value of shareholders' shares. With probability one the bank will eventually fail. Eventually the share value will go to zero. But these are big boys and girls. They know what they are doing. They are gambling with other people's money. If they lose it, the creditors of the bank will be paid by the government. The implication of the paper, which was written before deregulation, is that if there is deposit insurance you better regulate bank portfolios, because banks have incentives to become big and risky. If you are going to deregulate banks, you better reform deposit insurance.

I hate it when people like Paul Krugman say you macroeconomists completely missed the causes of the great financial crisis and models, so your competitive models with well-functioning markets are now totally discredited. It is not true. This kind of model actually alerted you to hazards that were put in the system. See Gary Stern and Ron Feldman's book Too Big to Fail: The Hazards of Bank Bailouts (2004). There is not an equation in it, but this reasoning is there. Stern and Feldman argue that the bad incentives are not with just the banks. They are with the statesmen and the voters, with the incentives ex post to do things which ex ante create really bad situations. Once you get into a crisis, all the considerations about moral hazard, to which people may have paid lip service, are out the window.

Larry Summers wrote an editorial after 
Northern Rock failed, and went after Mervyn King, the Governor of the Bank of England, for having made some very wise statements about moral hazard, and the need to do sensible things about bank capital. Summers said, now is not the time to bring out the moral hazard police. The question is, if not, then when?

So we have two diametrically opposed models. One puts multiple equilibria and runs at the center of things, and advocates deposit insurance and an active lender of last resort. These activities are good and costless. But the other says these solutions are setting up bigger and bigger time bombs. If you are an optimist, the Diamond-Dybvig model is right - people really would not want to gamble with the government's money, so we are probably fine.

Or you could be a pessimist and say the simple model of Kareken and Wallace hit the nail on the head. If so, the current situation really scares you. Because deposit insurance and lenders of last resort were problematic in 2006 and 2007, but now we have precedents to bail out the people they did not bail out before!

Let's not be pessimists. Let's hope that the Diamond-Dybvig model is right.

\section{Note}

1. This talk was given at Wake Forest University on February 11, 2011. 


\section{References}

Ahamed, L. (2009), Lords of Finance: The Bankers Who Broke the World, New York: Penguin.

Diamond, D.W. and P.H. Dybvig (1983), ‘Bank Runs, Deposit Insurance and Liquidity', Journal of Political Economy, 91 (3), 401-419.

Friedman, M. (1960), A Program for Monetary Stability, New York: Fordham University Press.

Kareken, J.H. and N. Wallace (1978), 'Deposit Insurance and Bank Regulation: A Partial-Equilibrium Exposition', Journal of Business, 51 (3), 413-438.

Smith, A. (1776), An Inquiry into the Nature and Causes of the Wealth of Nations, London: Methuen \& Co.

Stern, G. and R. Feldman (2004), Too Big to Fail: The Hazards of Bank Bailouts, Washington, DC: Brookings Institution. 